\title{
Karakteristik Morfometrik (Ukuran Linier dan Lingkar Tubuh) Sapi Persilangan Sumbawa x Bali (Sumbal) yang Dipelihara secara Semi Intensif di Kabupaten Sumbawa
}

\section{(Morphometric Characteristics (Linear Size and Body Circle) of Sumbawa x Bali (Sumbal) Crossbred Cattle That are Raised Semi-Intensively in Sumbawa Regency)}

\author{
Febriantus Aguantara, Tapaul Rozi, Maskur \\ Fakultas Peternakan Universitas Mataram, Jalan Majapahit Nomor 62 Mataram \\ E-mail: Febriantusaguantara2202@gmail.com
}

Diterima : 21 Oktober 2019/Disetujui : 22 Nopember 2019

\begin{abstract}
ABSTRAK
Penelitian ini bertujuan untuk mengetahui karakateristik morfometrik dari sapi persilangan Sumbawa x Bali (Sumbal) di Kabupaten Sumbawa. Materi yang digunakan yaitu Sapi Sumbal yang terdiri dari 14 ekor pedet, 20 ekor muda dan 27 ekor dewasa. Pengambilan sampel dilakukan secara purposive sampling/ dengan mengamati ciri-ciri morfometrik Sapi Sumbal. Hasil penelitian menunjukkan bahwa ukuran-ukuran tubuh Sapi Sumbal jantan tidak berbeda $(P>0,05)$ dengan betina pada kelompok umur pedet dan muda. Sedangkan pada kelompok umur dewasa, jantan lebih rendah dari betina $(P<0,05)$ pada parameter tinggi pinggul. Lingkar dada memiliki koefisien korelasi yang paling tinggi terhadap bobot badan diikuti tinggi badan dan panjang badan dengan nilai secara berurutan 0,$96 ; 0,83$; dan 0,80 . Persamaan $\mathrm{BB}=$ $173,104-1,837 \mathrm{~TB}+0,052 \mathrm{~PB}+4,493 \mathrm{LD}$ dan derajat determinasi $\left(\mathrm{R}^{2}\right)$ yaitu 0,939 diperoleh melalui analisis regresi. Lingkar dada dan tinggi badan secara signifikan $(P<0,05)$ mempengaruhi bobot badan sedangkan panjang badan tidak $(P>0,05)$ dan secara simultan berpengaruh terhadap bobot badan $(P<0,05)$.
\end{abstract}

Kata kunci: Karakteristik, Morfometrik, Koefisien Korelasi, Sapi Sumbal

\begin{abstract}
This study aims to determine the morphometric characteristics of the Sumbawa x Bali (Sumbal) crossbred cattle in Sumbawa Regency. The material used was Sumbal Cattle consisting of 14 calves, 20 young and 27 adults. Sampling was carried out by purposive sampling by observing morphometric characteristics of Sumbal cattle. The results show that body size of male Sumbal cattle was not different $(P>0.05)$ from female in the calf and young age groups. Whereas in the adult age group, male was lower than female $(P<0.05)$ in terms of hip height parameters. Chest circumference has the highest correlation coefficient on the body weight followed by height and body length with the values of 0,$96 ; 0,83$; and 0,80 respectively. The equation $\mathrm{BW}=-$ $173,104-1,837 \mathrm{H}+0,052 \mathrm{BL}+4,493 \mathrm{CC}$ and the degree of determination $\left(\mathrm{R}^{2}\right)$ of 0.939 was determined using regression analysis. Chest circumference and height had significantly $(P<0.05)$ effected the body weight whilst body length had not $(P>0.05)$ and simultaneously influences body weight $(P<0.05)$.
\end{abstract}

Keywords: Characteristics, Morphometrics, Correlation Coefficient, Sumbal Cattle

\section{PENDAHULUAN}

Sapi Sumbawa yang sebelumnya dikenal dengan nama Sapi Hissar merupakan ternak sapi yang awalnya berasal dari Punjab India dan didatangkan oleh pemerintah Hindia-Belanda pada tahun 1909 ke pulau Jawa dan pada tahun 1920 mulai menyebar ke pulau Sumatera dan pulau Sumbawa (Dilaga, 2014). Sedangkan Sapi Bali merupakan sapi potong asli Indonesia yang mempunyai kemampuan reproduksi tinggi, persentase karkas tinggi, daging tanpa lemak, heterosis 
positif tinggi pada persilangan, daya adaptasi yang tinggi terhadap lingkungan dan persentase kelahiran dapat mencapai 80 persen. Hal yang sama dikemukakan oleh Pane (1990) bahwa keunggulan Sapi Bali yaitu memiliki tingkat kesuburan yang tinggi, mampu memanfaatkan hijauan dengan nutrisi yang rendah, merupakan sapi pekerja yang baik, memiliki daging yang rendah subkutan dan heterosis yang positif.

Adanya seleksi negatif dalam kurun waktu yang cukup lama dan tanpa disadari oleh para peternak menyebabkan ternak Sapi Sumbawa maupun Sapi Bali saat ini mengalami penurunan mutu genetik yang cukup signifikan. Hal tersebut dapat dilihat dari kondisi performa yakni tubuh (tinggi pundak) yang kian pendek, ukuran tubuh mengecil, kaki memendek dan berat badan pun menurun. Hal tersebut merupakan akibat dari aktivitas inbreeding dan seleksi negatif (Bugiwati, 2007).

Sistem pemeliharaan yang diterpkan oleh Sapi Sumbal merupakan sapi hasil kawin silang secara alami antara Sapi Sumbawa jantan dan Sapi Bali betina. Terjadinya perkawinan silang antara Sapi Sumbawa dan Sapi Bali dapat menjadi solusi dari permasalahan akan pemenuhan kebutuhan daging dalam negeri akibat dari kondisi peternakan sapi potong dalam negeri yang secara umum masih sangat memprihatinkan. Menurut Hardjosubroto (1994), tujuan utama dari persilangan adalah menggabungkan dua sifat atau lebih yang berbeda yang semula terdapat dalam dua bangsa ternak ke dalam satu bangsa silangan.

Dalam melakukan tindak lanjut terhadap proses peningkatan mutu genetik melalui sapi hasil persilangan Sumbawa $\mathrm{x}$ Bali (Sumbal) maka perlu dilakukan proses seleksi untuk tetua untuk generasi selanjutnya. Menurut Warmadewi et al., (2015) seleksi dapat diartikan sebagai suatu proses dimana individu-individu tertentu dalam suatu populasi dipilih dan diternakkan untuk tujuan produksi yang lebih baik (segi kuantitas dan kualitas) pada generasi selanjutnya. Dasar dalam melakukan seleksi adalah karakteristik ternak itu sendiri yang mencerminkan sifatsifat yang dimiliki oleh ternak yang dapat dipengaruhi oleh gen dan lingkungan atau interaksi dari kedua faktor tersebut. Karakteristik yang dapat diamati dari seekor ternak yaitu karakteristik morfometrik (kuantitatif) yang meliputi bobot badan, panjang badan, tinggi badan, lingkar dada, tinggi panggul, ukuran kepala dan BCS (Body Condition Score). Semua jenis karakteristik tersebut mencerminkan performans produktivitas dari ternak yang bersangkutan. Selama ini kajian terhadap karakteristik morfometrik pada Sapi Sumbal ini belum pernah dilakukan. Oleh karena itu penelitian ini dilakukan untuk mengetahui karakteristik morfometrik sapi persilangan Sumbawa x Bali (Sumbal) yang dipelihara secara semi intensif di Kabupaten Sumbawa.

\section{MATERI DAN METODE}

\section{Materi Penelitian}

Sampel yang digunakan adalah sapi persilangan Sumbawa x Bali (Sumbal) yang terdiri dari 14 ekor pedet, 20 ekor muda dan 27 ekor dewasa yang dipelihara oleh peternak di Kecamatan Moyo Hilir, Moyo Hulu dan Moyo Utara Kabupaten Sumbawa.

\section{Metode Penelitian}

Metode penelitian dilakukan secara purposive sampling. Adapun variabel yang diamati yaitu sifat kualitatif berupa warna bulu dan bentuk tanduk yang dijadikan sebagai data sekunder serta data kuantitatif berupa bobot badan, panjang badan, tinggi badan, lingkar dada, tinggi pinggul, lebar kepala, panjang kepala dan BCS (Body Condition Score) yang dijadikan sebagai data primer. Data hasil pengukuran dan pengamatan tubuh Sapi Sumbal ditabulasi untuk mendapatkan nilai rata-rata dan standar deviasi dengan rumus sebagai berikut: 


$$
\begin{aligned}
& \bar{x}=\frac{\sum x}{n} \\
& \text { Keterangan: } \\
& \bar{x}=\text { rata-rata } \\
& \sum x=\text { jumlah nilai data } \\
& \mathrm{n}=\text { banyak data } \\
& S d=\sqrt{\frac{1}{n-1} \sum\left(x_{i}-\bar{x}\right)^{2}} \\
& \mathrm{Sd}=\text { standar deviasi } \\
& \mathrm{x}_{\mathrm{i}}=\text { nilai } \mathrm{x} \text { ke-i } \\
& \mathrm{n}=\text { banyak data } \\
& \bar{x}=\text { Rata-rata }
\end{aligned}
$$

Untuk mengetahui perbedaan rata-rata hasil pengukuran bagian morfometrik ternak Sapi Sumbal antara jenis kelamin jantan dan betina dilakukan dengan menggunakan analisis uji $\mathrm{t}$ dengan rumus sebagai berikut:

$$
t=\frac{\bar{X}_{1}-\bar{X}_{2}}{\sqrt{\frac{S_{1}^{2}}{n_{1}}+\frac{S_{2}^{2}}{n_{2}}}} \quad \begin{aligned}
& \text { Keterangan: } \\
& \overline{X_{1}}=\text { rata-rata sampel 1 } \\
& \overline{X_{2}}=\text { rata-rata sampel 2 } \\
& S_{1}^{2}=\text { varians sampel 1 } \\
& \\
& S_{2}^{2}=\text { varians sampel 2 } \\
& n_{1}=\text { banyak data sampel 1 } \\
& n_{2}=\text { banyak data sampel 2 }
\end{aligned}
$$

Nilai koefisien keragaman merupakan nilai memberikan gambaran tentang besarnya keragaman yang terdapat dalam suatu populasi ternak yang diukur. Nilai koefisien keragaman ukuran-ukuran linier tubuh Sapi Sumbal dianalisis menggunakan rumus sesuai dengan pendapat Warmadewi et al., (2017) yaitu:

$$
\mathrm{KK}=\frac{s d}{\bar{x}} X 100 \% \quad \begin{aligned}
& \text { Keterangan }: \\
& \mathrm{KK}=\text { Koefisien Keragaman } \\
& \mathrm{Sd}=\text { Standar deviasi } \\
& \bar{x}=\text { rata-rata }
\end{aligned}
$$

Nilai koefisien korelasi antara ukuranukuran morfometrik Sapi Sumbal dihitung menggunakan aplikasi Microsoft Excel. Menurut Sarwono (2006) koefisien korelasi merupakan nilai yang menunjukkan kuat atau tidaknya hubungan antara 2 variabel dan juga untuk mengetahui bentuk hubungan antara 2 variabel tersebut dengan hasil yang sifatnya kuantitatif. Nilai koefisien korelasi dapat bervariasi dari -1 sampai +1 . Nilai koefisien korelasi yang mendekati -1 atau +1 menunjukan hubungan yang kuat antara dua variabel tersebut dan nilai koefisien korelasi yang mendekati 0 mengindikasikan lemahnya hubungan antara dua variabel tersebut. Sedangkan tanda + (positif) dan - (negatif) memberikan informasi mengenai arah hubungan antara dua variabel tersebut. Jika bernilai + (positif) maka kedua variabel tersebut memiliki hubungan yang searah. Dalam arti lain peningkatan $\mathrm{X}$ akan bersamaan dengan peningkatan $\mathrm{Y}$ dan begitu juga sebaliknya. Jika bernilai - (negatif) artinya korelasi antara kedua variabel tersebut bersifat berlawanan. Peningkatan nilai $\mathrm{X}$ akan dibarengi dengan penurunan $\mathrm{Y}$.

Analisis regresi berganda ukuranukuran tubuh Sapi Sumbal dilakukan dengan bantuan aplikasi SPSS 2013. Hasil analisis regresi berganda dapat dibuat persamaan garis regresi berdasarkan petunjuk Arikunto (2006) yaitu sebagai berikut:

Keterangan : $Y_{C}=$ Variabel terikat $a=$ konstanta

$Y_{C}=\alpha+b_{1} X_{1}+b_{2} X_{2}+b_{3} X_{3}$

$\mathrm{b}=$ Koefisien regresi $\mathrm{X}_{1}=$ Variabel bebas 1 $\mathrm{X}_{2}=$ Variabel bebas 2 $\mathrm{X}_{3}=$ Variabel bebas 3

Hasil analisis regresi berganda dapat dilakukan uji t dan uji F. Uji t (uji parsial) digunakan untuk mengetahui pengaruh setiap variabel bebas (independen) terhadap variabel terikat (dependen). Kriteria pengujian hipotesis dengan menggunakan uji statistik $\mathrm{t}$ adalah jika nilai signifikansi $\mathrm{t}$ ( $p$-value $<0,05)$ maka dapat disimpulkan hipotesis alternative diterima yang menyatakan bahwa suatu variabel independen secara individual dan signifikan mempengaruhi variabel dependen. Sementara uji F (uji simultan) bertujuan untuk mengetahui ada atau tidaknya pengaruh simultan variabelvariabel bebas (independen) terhadap variabel terikat (dependen). Kriteria pengambilan keputusan dalam pengujian ini bisa dilaksanakan dengan menggunakan nilai probability value (p-value) maupun $\mathrm{F}$ hitung. Jika $p$-value $<0,05$ atau $\mathrm{F}$ hitung $\geq$ $F$ tabel maka hipotesis alternatif diterima yang menyatakan bahwa semua variabel independen secara simultan dan signifikan mempengaruhi variabel dependen (Ghozali, 2016). 


\section{HASIL DAN PEMBAHASAN}

\section{Sifat Kualitatif Sapi Sumbal}

Warna bulu pada Sapi Sumbal adalah perpaduan warna bulu dari kedua tetuanya yaitu Sapi Bali yang memiliki warna dominan merah bata sampai hitam dan Sapi Sumbawa yang memiliki warna dominan putih sampai hitam. Beatrizet et al (2007) menyatakan bahwa perpaduan antara warna bulu dari dua bangsa sapi yang berbeda akan mengahasilkan warna campuran (diluted) sehingga menghasilkan warna yang bervariasi pada keturunan F1. Warna bulu Sapi Sumbal pada saat masih pedet terdiri dari tiga warna baik pada jantan maupun betina yaitu merah keputihputihan (dominan warna bulu Sapi Bali), putih dengan warna kepala merah kecoklatan dan memiliki garis belut berwarna coklat, dan abu-abu (dominan warna bulu Sapi Sumbawa).

Pada saat mencapai umur dewasa, warna bulu Sapi Sumbal akan mengalami perubahan menjadi lebih gelap terutama pada bagian kepala, kaki, dan leher. Berdasarkan pengamatan warna Sapi Sumbal jantan dewasa ditemukan 3 warna yaitu hitam, merah kehitaman dan coklat. Sedangkan pada Sapi Sumbal betina dewasa memiliki warna bulu dengan berbagai variasi diantaranya abu-abu (dominan warna bulu Sapi Sumbawa), putih kekuningan (dominan warna bulu Sapi Sumbawa), merah bata muda dengan warna hitam pada bagian depan kepala dan kaki bagian depan serta leher (perpaduan), merah bata tua (perpaduan), merah bata (dominan warna bulu Sapi Bali) dan coklat muda (perpaduan). Fenomena perpaduan warna bulu yang hampir sama dengan Sapi Sumbal juga terjadi pada sapi persilangan lain seperti Sapi Limura (Limousin $\mathrm{x}$ Madura). Berdasarkan pendapat Hartatik et al. (2009) warna bulu pada Sapi Limura adalah sebagian besar merah bata (45\%) dan merah gelap (35\%). Hal yang sama juga di laporkan oleh Bambang (2015) yang menyatakan bahwa warna bulu yang menonjol pada Sapi Katingan betina adalah coklat kemerahan (27\%) dan coklat keputihan $(14,1 \%)$

Diketahui Sapi Sumbal memiliki 5 variasi bentuk tanduk yaitu (a) melengkung keatas (b) panjang miring keatas (c) asimetris (d) panjang bergelombang ke atas dan (e) melengkung ke depan. Bentuk tanduk yang hampir sama juga ditemukan oleh Sudrajad dan Subiharta (2015) pada Sapi Peranakan Ongole yaitu pendek, panjang kebelakang, panjang keatas, lengkung kebawah, lengkung kesamping dan asimetris.

\section{Karakterisitik Morfometrik (Kuantitatif) Sapi Persilangan Sumbawa x Bali (Sumbal).}

Hasil pengukuran dan pengamatan karakteristik morfometrik Sapi Sumbal menunjukkan bahwa nilai rata-rata hasil pengukuran bagian morfometrik Sapi Sumbal bertambah seiring dengan bertambahnya umur. Kecepatan tumbuh sapi potong yang sebenarnya meningkat sesuai dengan peningkatan umur sampai saat tertentu dan kemudian menurun lagi sampai konstan.

Dari hasil rata-rata dan standar deviasi hasil pengukuiran bagian morfometrik Sapi Sumbal dapat diketahui koefisien keragaman. Nilai koefisien keragaman yang lebih dari 0,5 menandakan bahwa data yang diperoleh heterogen atau beragam. Nilai koefisien keragaman yang tertinggi didapat pada pengukuran bobot badan pedet Sapi Sumbal betina yaitu sebesar 0,57 sehingga dapat dikatakan bahwa data pengukuran bobot badan sapi sumbal betina pada umur pedet ini bersifat heterogen atau beragam (koefisen keragaman $>0,5)$.

Rata-rata pengukuran bobot badan Sapi Sumbal jantan tidak jauh berbeda dengan bobot badan Sapi Sumbal betina $(P>0,05)$ pada semua kelompok umur. Hasil tersebut tidak sesuai dengan penelitian-penelitian sebelumnya yang menyatakan bahwa laju pertumbuhan ternak jantan lebih cepat daripada ternak 
betina. Menurut Soeparno (1992) ternak jantan memiliki hormon androgen yang merupakan hormon kelamin yang hasilkan oleh testes dan berfungsi menstimulasi sintesis protein terutama didalam otot sehingga mengakibatkan pertumbuhan menjadi lebih cepat. Namun apabila kita mengamati proses pertumbuhan pada seekor ternak, terdapat beberapa faktor yang dapat mempengaruhi laju pertumbuhan seekor ternak selain jenis kelamin yaitu faktor genetik dan manajemen pemeliharaan. Menurut Hamdani et al., (2017) laju pertumbuhan seekor ternak dapat dipengaruhi oleh faktor genetik, lingkungan, pakan, manajemen dan jenis kelamin. Pada kelompok umur pedet, Sapi Sumbal memiliki rata-rata bobot badan yaitu $68,67 \pm 33,41$ pada jantan

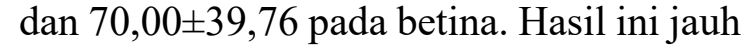

lebih rendah dari rata-rata bobot badan Sapi Bali pada kelompok umur 0-1 tahun (pedet) seperti yang dikemukakan oleh Latulamamina (2013) yaitu $160,30 \pm 39,69$ pada jantan dan $100,43 \pm 52,13$ pada betina. Sementara itu pada Sapi Sumbal muda (1-2 tahun) diperoleh rata-rata bobot badan yaitu $231,20 \pm 79,00$ pada jantan dan $243,88 \pm 86,78$ pada betina. Hasil ini lebih tinggi dari hasil pengukuran bobot badan Sapi Bali pada kelompok umur muda (1-2 tahun) seperti yang dikemukakan oleh Latulamamina (2013) yaitu $187,00 \pm 50,20$ pada jantan dan $214,29 \pm 65,00$ pada betina. Hal ini dapat dikatakan bahwa Sapi Sumbal memiliki laju pertumbuhan yang lebih cepat daripada Sapi Bali sebagai salah satu bangsa tetuanya yang dapat dilihat dari pertambahan bobot badan dari umur pedet ( $>1$ tahun) sampai umur muda (1-2 tahun).

Tabel 3. Karakteristik morfometrik sapi persilangan Sumbawa x Bali (Sumbal) (rata-rata \pm SD)

\begin{tabular}{clcccc}
\hline \multirow{2}{*}{ Parameter } & \multicolumn{1}{c}{$\begin{array}{c}\text { Umur } \\
\text { (tahun) }\end{array}$} & \multicolumn{2}{c}{ Jenis kelamin } & \multicolumn{2}{c}{ Koefisien Keragaman (\%) } \\
\cline { 3 - 6 } & Pedet $(<1)$ & $68,67 \pm 33,41$ & $70,00 \pm 39,76$ & 0,49 & 0,57 \\
\cline { 2 - 6 } BB & Muda $(1-2)$ & $231,20 \pm 79,00$ & $243,88 \pm 86,78$ & 0,34 & 0,36 \\
\cline { 2 - 6 } & Dewasa $(>2)$ & $299,00 \pm 77,44$ & $337,06 \pm 70,80$ & 0,26 & 0,21 \\
\hline \multirow{2}{*}{ TB } & Pedet $(<1)$ & $92,17 \pm 13,64$ & $83,63 \pm 19,32$ & 0,15 & 0,23 \\
\cline { 2 - 6 } & Muda $(1-2)$ & $114,40 \pm 6,56$ & $116,88 \pm 6,73$ & 0,06 & 0,06 \\
\cline { 2 - 6 } & Dewasa $(>2)$ & $118,67 \pm 9,22$ & $122,56 \pm 8,71$ & 0,08 & 0,07 \\
\hline \multirow{2}{*}{ PB } & Pedet $(<1)$ & $82,33 \pm 14,02$ & $72,88 \pm 19,30$ & 0,17 & 0,26 \\
\cline { 2 - 6 } & Muda $(1-2)$ & $117,55 \pm 22,57$ & $112,00 \pm 13,85$ & 0,19 & 0,12 \\
\cline { 2 - 6 } & Dewasa $(>2)$ & $119,44 \pm 13,09$ & $126,11 \pm 11,49$ & 0,11 & 0,09 \\
\hline \multirow{3}{*}{ LD } & Pedet $(<1)$ & $86,00 \pm 21,58$ & $85,63 \pm 21,03$ & 0,25 & 0,25 \\
\cline { 2 - 6 } & Muda $(1-2)$ & $138,70 \pm 15,71$ & $141,25 \pm 18,31$ & 0,11 & 0,13 \\
\cline { 2 - 6 } & Dewasa $(>2)$ & $153,00 \pm 14,90$ & $159,61 \pm 12,14$ & 0,10 & 0,08 \\
\hline \multirow{2}{*}{ TP } & Pedet $(<1)$ & $91,00 \pm 15,47$ & $84,13 \pm 20,61$ & 0,17 & 0,24 \\
\cline { 2 - 6 } & Muda $(1-2)$ & $116,05 \pm 7,26$ & $117,25 \pm 9,50$ & 0,06 & 0,08 \\
\cline { 2 - 6 } & Dewasa $(>2)$ & $117,11 \pm 9,64$ & $127,83 \pm 16,51$ & 0,08 & 0,13 \\
\hline \multirow{2}{*}{ LK } & Pedet $(<1)$ & $12,83 \pm 1,17$ & $12,13 \pm 1,46$ & 0,09 & 0,12 \\
\cline { 2 - 6 } & Muda $(1-2)$ & $17,50 \pm 2,01$ & $17,38 \pm 1,85$ & 0,11 & 0,11 \\
\cline { 2 - 6 } & Dewasa $(>2)$ & $19,78 \pm 2,95$ & $19,22 \pm 2,69$ & 0,15 & 0,14 \\
\hline \multirow{2}{*}{ PK } & Pedet $(<1)$ & $24,00 \pm 3,85$ & $24,50 \pm 6,57$ & 0,16 & 0,27 \\
\cline { 2 - 6 } & Muda $(1-2)$ & $37,20 \pm 3,40$ & $36,13 \pm 4,64$ & 0,09 & 0,13 \\
\cline { 2 - 6 } & Dewasa $(>2)$ & $38,33 \pm 5,00$ & $37,94 \pm 5,48$ & 0,13 & 0,14 \\
\hline
\end{tabular}

Keterangan $: \mathrm{BB}=$ Bobot Badan, $\mathrm{TB}=$ Tinggi Badan, $\mathrm{PB}=$ Panjang Badan, $\mathrm{LD}=$ Lingkar Dada, $\mathrm{TP}=$ Tinggi Pinggul, LK = Lebar Kepala, PK = Panjang Kepala

Pada hasil pengukuran tinggi badan Sapi Sumbal dapat diketahui Sapi Sumbal jantan memiliki rata-rata ukuran yang tidak jauh berbeda $(P>0,05)$ dengan Sapi Sumbal betina pada semua kelompok umur. Hasil ini kurang selaras dengan pendapat Parakkasi (1999) yang menyatakan bahwa laju pertumbuhan ternak jantan lebih cepat 
dibandingkan dengan ternak betina. Dikatakan pula bahwa jenis kelamin memiliki peranan yang sangat penting dalam merangsang pertumbuhan. Pada Sapi Sumbal dewasa ( $>2$ tahun) didapat hasil pengukuran tinggi badan yaitu $118,67 \pm 9,22$ pada jantan dan $122,56 \pm 8,71$ pada betina. Hasil ini lebih tinggi dari pengukuran tinggi badan pada Sapi Pasundan dewasa seperti yang dikemukakan oleh Nugraha et al., (2016) yaitu $114,98 \pm 1,82$ pada jantan dan $107,97 \pm 2,97$ pada betina.

Rata-rata hasil pengukuran panjang badan pada Sapi Sumbal jantan tidak berbeda jauh dengan Sapi Sumbal betina $(P>0,05)$ pada semua kelompok umur. Hasil ini kurang mendukung pendapat Soeparno (1992) yang menyatakan bahwa sapi jantan memiliki pertumbuhan yang lebih cepat daripada sapi betina. Hal ini dikarenakan pada sapi jantan memiliki hormon androgen yang merupakan hormon kelamin yang hasilkan oleh testes berfungsi menstimulasi sintensis protein protein terutama didalam otot sehingga mengakibatkan pertumbuhan menjadi lebih cepat.

Ukuran lingkar dada pada Sapi Sumbal jantan memiliki nilai rata-rata yang tidak jauh berbeda $(P>0,05)$ dengan Sapi Sumbal betina. Berbeda dengan pendapat Hamdani et al., (2017) yang menyatakan bahwa ternak jantan memiliki ukuran lingkar dada yang lebih besar dibandingkan ternak betina yang dikarenakan perbedaan kecepatan pertumbuhan antara sapi jantan dan betina. Hasil pengukuran lingkar dada pada Sapi Sumbal kelompok umur pedet $(<$ 1 tahun) yaitu $86,00 \pm 21,58$ pada jantan dan $85,63 \pm 21,03$ pada betina. Hasil ini jauh lebih rendah dibandingkan lingkar dada Sapi Krui pada umur 0-1 tahun (pedet) seperti yang dikemukakan oleh Hamdani et al., (2017) yaitu $118,00 \pm 10,5$ pada jantan $110,00 \pm 8,7$ pada betina. Sementara itu pada Sapi Sumbal kelompok umur muda (1-2 tahun) diperoleh rata-rata hasil pengukuran lingkar dada yaitu $138,70 \pm 15,71$ pada jantan dan $141,25 \pm 18,31$ pada betina. Hasil rata-rata pengukuran lingkar dada pada Sapi Sumbal jantan muda ini tidak jauh berbeda dengan rata-rata lingkar dada Sapi Bali jantan muda yang dikemukakan oleh Zurahmah dan Enos (2011) yaitu $138,84 \pm 6,82$.

Pada pengukuran tinggi pinggul, Sapi Sumbal jantan memiliki ukuran yang tidak berbeda jauh dengan Sapi Sumbal betina $(P>0,05)$ pada kelompok umur pedet dan muda. Sedangkan pada kelompok umur dewasa, Sapi Sumbal jantan memiliki ukuran tinggi pinggul $(P<0,05)$ yang lebih rendah daripada betina. Pada Sapi Sumbal muda diperoleh rata-rata pengukuran tinggi pinggul yaitu $116,05 \pm 7,26$ pada jantan dan $117,25 \pm 9,50$ pada betina. Rata-rata tinggi pinggul pada Sapi Sumbal jantan muda tersebut lebih besar dari tinggi pinggul Sapi Bali jantan muda seperti yang dikemukakan oleh Mahmudi et al., (2019) yaitu 109,35 $\pm 7,18$. Sementara itu hasil pengukuran tinggi pinggul pada Sapi Sumbal betina umur muda ini lebih besar lebih besar dari tinggi pinggul sapi Peranakan Ongole betina pada umur yang sama yaitu 112,10 $\pm 1,94$ (Mahmudi et al., 2019).

Pada pengukuran lebar kepala, Sapi Sumbal jantan memiliki ukuran yang tidak berbeda nyata $(P>0,05)$ dengan Sapi Sumbal betina. Hasil pengukuran lebar kepala pada Sapi Sumbal muda jantan yaitu $17,50 \pm 2,01$ tidak berbeda jauh dengan hasil penelitian dari Hartati et al., (2010) pada Sapi Peranakan Ongole jantan dengan umur yang sama yaitu umur muda yaitu dengan nilai $19,90 \pm 1,7$.

Pada pengukuran panjang kepala, Sapi Sumbal jantan memiliki ukuran yang tidak jauh berbeda $(P>0,05)$ dengan Sapi Sumbal betina. Rata-rata hasil pengukuran panjang kepala pada Sapi Sumbal jantan muda yaitu 37,20 $\pm 3,40$ lebih rendah dari panjang kepala Sapi Peranakan Ongole jantan muda yaitu 44,90 $\pm 5,3$ (Hartati et al, 2010). 


\section{Body Condition Score (BCS) Sapi Persilangan Sumbawa x Bali (Sumbal).}

Berdasarkan hasil pengamatan BCS (Body Condition Score) pada Sapi Sumbal menunjukkan bahwa jantan memiliki ratarata nilai BCS yang tidak berbeda dengan betina $(P>0,05)$. Sapi Sumbal betina dewasa memiliki rata-rata BCS yang tertinggi pada semua hasil pengamatan yaitu dengan nilai 2,61 $\pm 0,85$. Besar kecilnya BCS tidak dipengaruhi oleh umur melainkan asupan nutrisi yang didapat. Apabila dilihat secara keseluruhan, Sapi Sumbal yang diamati memiliki BCS yang terbilang cukup rendah yaitu antara sangat kurus sampai sedang yaitu skor $1(1,45 \%)$, skor $2(63,77 \%)$, skor $3(24,64 \%)$ dan skor $4(10,14 \%)$. Hal ini dapat disebabkan oleh beberapa diantaranya manajemen pemeliharaan yang kurang memadai dan ketersediaan pakan yang memiliki nilai nutrisi yang tinggi yang sedikit.

Tabel 4. Body Condition Score sapi persilangan Sumbawa x Bali (Sumbal) (rata-rata \pm SD)

\begin{tabular}{cllccc}
\hline \multirow{2}{*}{ Parameter } & \multirow{2}{*}{ Umur (tahun) } & \multicolumn{2}{c}{ Jenis kelamin } & \multicolumn{2}{c}{$\begin{array}{c}\text { Koefisien } \\
\text { Keragaman (\%) }\end{array}$} \\
\cline { 2 - 6 } & & Jantan & Betina & Jantan & Betina \\
\hline \multirow{3}{*}{ BCS } & Pedet $(<1)$ & $2,17 \pm 0,41$ & $2,13 \pm 0,35$ & 0,19 & 0,16 \\
\cline { 2 - 6 } & Muda $(1-2)$ & $2,50 \pm 0,76$ & $2,25 \pm 0,46$ & 0,30 & 0,20 \\
\cline { 2 - 6 } & Dewasa $(>2)$ & $2,44 \pm 0,73$ & $2,61 \pm 0,85$ & 0,30 & 0,33 \\
\hline
\end{tabular}

Keterangan: $\mathrm{BCS}=$ Body Condition Score

\section{Koefisien Korelasi Peubah-Peubah Fenotipik Sapi Persilangan Sumbawa $x$ Bali (Sumbal)}

Lingkar dada memiliki koefisien korelasI paling tinggi terhadap bobot badan diikuti tinggi badan dan panjang badan dengan nilai secara berurutan 0,$96 ; 0,83$ dan 0,80 . Hasil ini sesuai dengan pendapat White and Green dalam Yurnalis (2007) yang menyatakan bahwa koefisien korelasi antara lingkar dada, panjang badan dan tinggi pundak mempunyai pengaruh yang tinggi terhadap bobot hidup dibandingkan dengan ukuran tubuh lainnya.

Tabel 5. Koefisien korelasi $\left(\mathrm{r}^{2}\right)$ bobot badan dan peubah morfometrik Sapi Persilangan Sumbawa x Bali (Sumbal) dilokasi penelitian.

\begin{tabular}{lcccccccc}
\hline & $\begin{array}{c}\text { Bobot } \\
\text { badan }\end{array}$ & $\begin{array}{c}\text { Tinggi } \\
\text { badan }\end{array}$ & $\begin{array}{c}\text { Panjang } \\
\text { badan }\end{array}$ & $\begin{array}{c}\text { Lingkar } \\
\text { dada }\end{array}$ & $\begin{array}{c}\text { Tinggi } \\
\text { pinggul }\end{array}$ & $\begin{array}{c}\text { Lebar } \\
\text { kepala }\end{array}$ & $\begin{array}{c}\text { Panjang } \\
\text { kepala }\end{array}$ & BCS \\
\hline Bobot badan & 1,00 & & & & & & & \\
\hline Tinggi badan & $\mathbf{0 , 8 3}$ & 1,00 & & & & & & \\
\hline Panjang badan & $\mathbf{0 , 8 0}$ & 0,83 & 1,00 & & & & & \\
\hline Lingkar dada & $\mathbf{0 , 9 6}$ & 0,91 & 0,85 & 1,00 & & & & \\
\hline Tinggi pinggul & 0,76 & 0,93 & 0,77 & 0,84 & 1,00 & & & \\
\hline Lebar kepala & 0,77 & 0,79 & 0,69 & 0,80 & 0,73 & 1,00 & & \\
\hline Panjang kepala & 0,72 & 0,81 & 0,73 & 0,80 & 0,72 & 0,74 & 1,00 & \\
\hline BCS & 0,66 & 0,43 & 0,44 & 0,55 & 0,33 & 0,36 & 0,35 & 1,00 \\
\hline
\end{tabular}

Lingkar dada memiliki nilai koefisien korelasi yang paling kuat dengan nilai sebesar 0,96. Hal ini sejalan dengan pendapat Malewa (2009) yang menyatakan bahwa lingkar dada memiliki korelasi yang palinga kuat terhadap bobot badan dengan nilai korelasi 0,91 pada Domba Donggala.
Gunawan dan Putra (2016) juga menjelaskan lingkar dada memberikan korelasi tertinggi terhadap bobot badan Sapi Peranakan Ongole betina dengan nilai korelasi sebesar 0,91. Hal serupa juga dijelaskan oleh Gunawan dan Jakaria (2011) yang menunjukkan lingkar dada 
memiliki korelasi tertinggi terhadap bobot badan Sapi Bali yaitu sebesar 0,84 dan 0,87 untuk masing-masing bobot sapih dan bobot setahun. Hal ini diduga karena lingkar dada berhubungan langsung dengan dada dan ruang abdomen dimana sebagian besar bobot badan ternak berasal dari bagian dada hingga pinggul. Hal itu berarti semakin besar ukuran lingkar dada pada ternak maka bobot badannya juga semakin besar atau berat.

Ketiga peubah morfometrik tersebut selanjutnya dapat dijadikan sebagai salah satu cara untuk menduga persamaan regresi linier berganda yang paling baik sebagai penduga bobot badan dari Sapi Sumbal dengan menggunakan analisis regresi dari tinggi badan, panjang badan dan lingkar dada terhadap bobot badan. Persamaan regresi linier berganda merupakan persamaan matematik yang bertujuan mencari nilai variabel terikat (dependen) dari dua atau lebih nilai variabel terikat (independen) (Arikunto, 2006). Dari hasil analisis regresi berganda dari tinggi badan, panjang badan dan lingkar dada terhadap bobot badan dapat diperoleh persamaan yaitu $\mathrm{BB}=-173,104-1,837 \mathrm{~TB}+0,052 \mathrm{~PB}$ $+4,493$ LD. Nilai koefisien regresi dari lingkar dada adalah 4,493 yang berarti setiap kenaikan $1 \mathrm{~cm}$ dari dari lingkar dada maka akan berdampak pada kenaikan bobot badan sebesar 4,493 kg.

Dari hasil analisis regresi tinggi badan, panjang badan dan lingkar dada terhadap bobot badan Sapi Sumbal dapat diketahui derajat determinasi atau $\mathrm{R}^{2}(\mathrm{R}$ square). Nilai derajat deterninasi $\left(R^{2}\right)$ ini menerangkan seberapa jauh kemampuan model dalam menerangkan variasi variabel dependen dengan nilai antara nol dan satu (Ikhsanuddin et al., 2018). Adapun nilai derajat determinansi atau $\mathrm{R}^{2}(\mathrm{R}$ square) yaitu diperoleh adalah 0,939 yang menandakan bahwa pengaruh variabel tinggi badan, panjang badan dan lingkar dada terhadap bobot badan sebesar 93,9\%.
Berdasarkan hasil uji t (uji parsial) dapat disimpulkan bahwa lingkar dada dan tinggi badan Sapi Sumbal pada penelitian ini berpengaruh secara individual dan signifikan terhadap bobot badan Sapi Sumbal dengan nilai signifikansi 0,000 dan $0,001(P<0,05)$. Sedangkan pada parameter panjang badan Sapi Sumbal tidak mempunyai pengaruh terhadap bobot badan Sapi Sumbal karena nilai signifikansi 0,856 $(P>0,05)$. Berdasarkan hasil uji $\mathrm{F}$ dapat disimpulkan bahwa tinggi badan, panjang badan dan lingkar dada mempunyai pengaruh dan signifikan secara simultan terhadap bobot badan Sapi Sumbal yaitu dengan nilai signifikansi $0,000(P<0,05)$.

\section{KESIMPULAN DAN SARAN}

\section{Kesimpulan}

Ukuran-ukuran tubuh Sapi Sumbal jantan tidak berbeda dengan ukuran-ukuran tubuh Sapi Sumbal betina pada kelompok umur pedet dan muda. Sedangkan pada kelompok umur dewasa, parameter tinggi pinggul jantan lebih rendah dari betina. Lingkar dada memiliki korelasi yang paling tinggi terhadap bobot badan diikuti tinggi badan dan panjang badan dengan nilai secara berurutan 0,$96 ; 0,83$; dan 0,80 . Dari hasil analisis regresi diperoleh persamaan $\mathrm{BB}=-173,104-1,837 \mathrm{~TB}+0,052 \mathrm{~PB}+$ 4,493 $\mathrm{LD}$ dan derajat determinasi $\mathrm{R}^{2}$ ( $\mathrm{R}$ square) yaitu 0,939. Lingkar dada dan tinggi badan Sapi Sumbal memiliki pengaruh terhadap bobot badan. Sedangkan panjang badan tidak memiliki pengaruh terhadap bobot badan dan secara simultan berpengaruh terhadap bobot badan.

\section{Saran}

Perlu adanya penelitian lebih lanjut karakteristik morfometrik Sapi persilangan Sumbawa x Bali (Sumbal) yang sudah jelas keturunan F1 ataupun hasil backcross serta penelitian terhadap keragaman genetik dari Sapi Sumbal itu sendiri sehingga nantinya dapat dijadikan sebagai dasar dalam melakukan seleksi yang lebih baik lagi. 


\section{DAFTAR PUSTAKA}

Arikunto, S. 2006. Metode Penelitian Kualitatif. Jakarta: Bumi Aksara.

Bambang N.U., 2015. Sapi Katingan Sapi Lokal Kalimantan Tengah Upaya Pelestariannya. J. Litbang Pert. 34 (3): 135-145.

Beatriz, G.G., P. Wiener, and J.L. Williams. 2007. Genetic effects on coat colour in cattle: dilution of eumelanin and phaeomelanin pigments in an F2Backcross Charolais $\times$ Holstein population. BMC Genetics 7(8):56.

Bugiwati, S. R. A. 2007. Pertumbuhan Dimensi Tubuh Pedet Jantan Sapi Bali di Kabupaten Bone dan Barru Sulawesi Selatan. Jurnal Sains dan Teknologi 7:103-108.

Dilaga, S.H., 2014. Sapi Sumbawa Sumber Daya Genetik Ternak Indonesia. Bandung: Pustaka Reka Cipta.

Ghozali, Imam. 2016. Aplikasi Analisis Multivariete dengan Program IBM SPSS 23 (Edisi 8). Cetakan ke VIII. Badan Penerbit Universitas Diponegoro, Semarang.

Gunawan A dan B. W. Putera. 2016. Aplikasi Linier Ukuran Tubuh untuk Seleksi Fenotipik Bibit Induk Sapi PO di Kabupaten Bojonegoro. Jurnal Ilmu Produksi dan Teknologi Hasil Peternakan. Vol 4, No 3 (2016)

Gunawan A. dan Jakaria. 2011. Genetic and non Genetics Effect on Birth, Weaning, and Yearling Weight of Bali Cattle. Med. Pet.34: 93-98. Doi: 10.5398/medpet.2011.34.2.93

Hamdani M.D.I., K. Adhianto, Sulastri, A. Husni dan Renitasari. 2017. Ukuran-Ukuran Tubuh Sapi Krui Jantan dan Betina di Kabupaten
Pesisir Barat Lampung. Jurnal Ilmu Ternak. 17 (2): 99-105.

Hardjosubroto, W. 1994. Aplikasi Pemuliabiakan Ternak di Lapangan. Jakarta: PT. Gramedia Widiasarana Indonesia.

Hartati, Sumadi, Subandriyo dan T. Hartatik, 2010. Keragaman Morfologi dan Differensiasi Genetik Sapi Peranakan Ongole di Peternakan Rakyat. JITV 15 (1):7280.

Hartatik T., D.A. Mahardika, T.S.M. Widi, dan E. Baliarti. 2009. Karakteristik dan Kinerja Induk Sapi Silangan Limousin x Madura dan Madura di Kabupaten Sumenep dan Pamekasan. J. Buletin Peternakan. 33 (3):143-147.

Ikhsanuddin, V.M.A. Nurgiartiningsih, Kuswati, dan Zainuddin. 2018. Korelasi Ukuran Tubuh terhadap Bobot Badan Sapi Aceh Umur Sapih dan Umur Satu Tahun. J. Agripet. 18 (2): 117-122.

Latulamamina, M. 2013. Korelasi antara Umur dan Berat Badan Sapi Bali (Bos Sondaicus) di Pulau Seram. Agrinimal. 3 (1): 35-40.

Mahmudi, R. Priyanto dan Jakaria. 2019. Karakteristik Morfometrik Sapi Aceh, Sapi PO dan Sapi Bali Berdasarkan Analisis Komponen Utama (AKU). Jurnal Ilmu Produksi dan Teknologi Hasil Peternakan. 7 (1): 35-40.

Malewa, A. 2009. Penaksiran bobot badan berdasarkan lingkar dada dan panjang domba Donggala. J. Agroland 16:91-97.

Nugraha D.D., E.Y. Setyowati dan N. Suwarno. 2016. Karakteristik Kuantitatif Sapi Pasundan di Peternakan Rakyat. 5 (4): 1-10. 
Pane, I. 1990. Upaya Peningkatan Mutu Genetik Sapi Bali di P3 Bali. Prosiding Seminar Nasional Sapi Bali. Bali, 20-22 September 1990.

Parakkasi, A. 1999. Ilmu Nutrisi dan Makanan Ternak Ruminan. Cetakan Pertama Penerbit UP. Jakarta

Soeparno. 1992. Ilmu dan Teknologi Daging. Gajah Mada University. Yogyakarta

Sudrajad P dan Subiharta. 2014 Phenotypic Characteristics of Ongole Grade Cows in Kebumen. https://www.researchgate.net/publi cation/281490182

Warmadewi, D.A., I.G.L. Oka dan I.N. Ardika. 2017. Efektivitas Seleksi Dimensi Tubuh Sapi Bali Induk. Jurnal Ilmiah Peternakan. 20 (1): 16-19.

Warmadewi, D.A., I.G.L. Oka, N.P. Sarini, I.N. Ardika, M. Dewantari. 2015. Bahan Ajar Ilmu Pemuliaan Ternak. Program Studi Peternakan Fakultas Peternakan Universitas Udayana, Denpasar.

Yurnalis, 2007. Pembentukan Rumus Sederhana Pendugaan Bobot Hidup Sapi Persilangan Simental dengan PO berdasarkan Ukuran Tubuh. Jurnal. Peternakan Indonesia. 12 (2): 156-164.

Zurahmah N. dan Enos T., 2011. Pendugaan Bobot Badan Calon Pejantan Sapi Bali Menggunakan Dimensi Ukuran Tubuh. Buletin Peternakan. 35 (3): 160-164. 